\title{
Autologous Creatinine Clearance in a Case of Necrotizing Fasciitis and Anuria
}

\author{
Michael T. Eadon Jay L. Koyner \\ Section of Nephrology, University of Chicago, Chicago, III., USA
}

\section{Key Words}

Necrotizing soft tissue infection $\cdot$ Fasciitis $\cdot$ Acute renal

failure $\cdot$ Burn $\cdot$ Debridement

\begin{abstract}
Necrotizing fasciitis can present with concomitant acute kidney injury. The etiology of acute kidney injury is often multifactorial; potential sources include volume depletion, abdominal compartment syndrome, rhabdomyolysis, and acute tubular necrosis (which may be related to hemodynamic instability, medications, or sepsis/infection). Kidney injury, defined via changes in serum creatinine, portends increased morbidity and mortality. Thus, it is crucial to accurately diagnose and assess the severity of kidney injury. We present the case of a patient with necrotizing fasciitis who endured 31 consecutive days of complete anuria. His serum creatinine decreased over this interval without the use of extracorporeal hemofiltration or dialysis. The explanation for this novel phenomenon lies in massive daily sero-sanguineous discharge and insensible losses with subsequent volume resuscitation. The patient's own convective clearance was substantial enough to maintain a modest creatinine clearance of $15 \mathrm{ml} / \mathrm{min}$ during sustained anuria. Our case emphasizes the importance of employing the creatinine, estimated glomerular filtration rate, and urine output
\end{abstract}

portions of the Acute Kidney Injury Network (AKIN) or Risk Injury Failure Loss End stage (RIFLE) criteria in assessing the severity of kidney injury. It further reinforces the imperfection in using serum creatinine as a primary measure of glomerular filtration rate.

Copyright $\odot 2012$ S. Karger AG, Basel

\section{Case Report}

A 56-year-old morbidly obese African-American male with a history of diabetes mellitus (baseline creatinine $0.8 \mathrm{mg} / \mathrm{dl}$ ) presented to the emergency center with a 5-day history of fevers, chills, and painful swelling of his right anterior proximal thigh. Examination revealed a $12-\mathrm{cm}$ malodorous, firm, erythematous region of the right lower extremity with extension to the groin. $\mathrm{He}$ had bullae, crepitus, and a cutaneous tract with exudative drainage. He was diagnosed with a necrotizing soft tissue infection (NSTI) and underwent emergent surgical debridement. During his 91-day hospitalization, the patient underwent 15 surgical explorations and debridements. Skin and soft tissue were excised circumferentially down to exposed muscle from his xyphoid process to just above his right knee (fig. 1a); total body surface area of debridement was $35 \%$. He had considerable insensible losses and massive sero-sanguineous drainage from his wounds. Drainage collection was quantified using an Exu-Dry ${ }^{\circledR}$ dressing and Yankauer suction device (fig. 1b) and averaged $9.9 \pm 6.6$ (mean $\pm \mathrm{SE}$ ) liters daily. To maintain adequate blood pressure, the patient received a mean of $21.8 \pm 14.0$ liters of intravenous lactated Ringer's solution and blood products daily. Despite aggressive

\section{KARGER}

Fax +41613061234 E-Mail karger@karger.ch www.karger.com
(C) 2012 S. Karger AG, Basel

0250-8095/12/0353-0225\$38.00/0

Accessible online at:

www.karger.com/ajn
Michael T. Eadon

5841 South Maryland Ave., Suite S511, MC 5100

Chicago, IL 60637 (USA)

Tel. +1 7737024843

E-Mail Michael.eadon@uchospitals.edu 
Fig. 1. Skin and soft tissue were excised circumferentially down to exposed muscle (a) with 35\% total body surface area of debridement. Massive wound output was collected using an Exu-Dry ${ }^{\circledR}$ dressing (b) and Yankauer suction device.
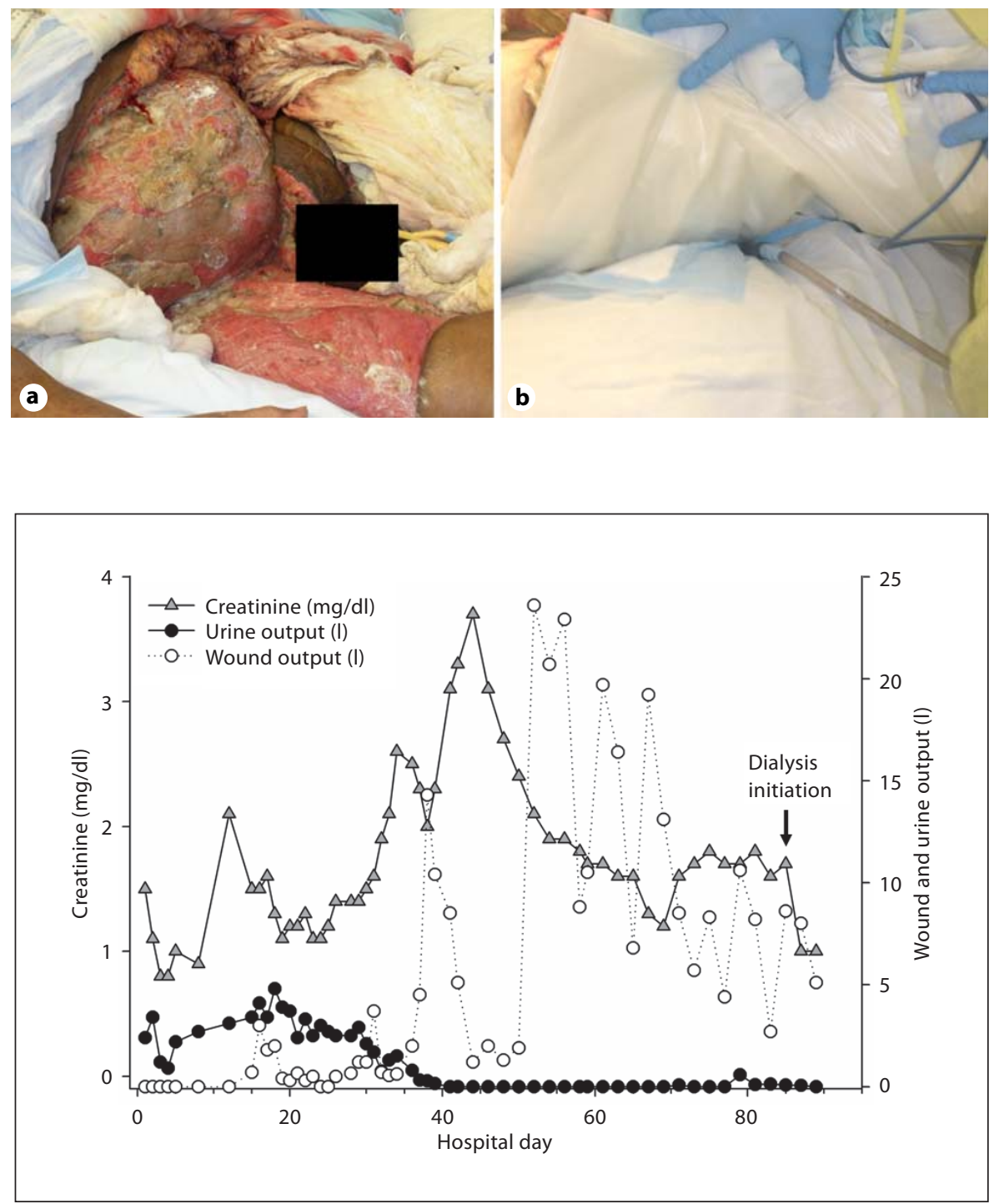

Fig. 2. Time course for serum creatinine, urine output, and wound output is given. The patient's serum creatinine decreased during sustained anuria, while wound output increased. Dialysis was not initiated until hospital day 85 . volume replacement, he intermittently required vasopressor and ionotropic support. He was intubated and ventilated during debridement on hospital day 1 and remained ventilated throughout hospitalization (tracheostomy day 36).

On presentation, his creatinine was elevated to $1.4 \mathrm{mg} / \mathrm{dl}$ and returned to baseline with appropriate volume repletion (fig. 2). Serum creatinine kinase was elevated to $664 \mathrm{U} / \mathrm{l}$ on admission and gradually returned to normal levels. Throughout the first 4-5 days, urine output remained robust (approx. 2 liters); however, post-debridement hypotension (MAP 53) on day 7 resulted in non-oliguric acute kidney injury (AKI) on hospital days 9-16 (peak creatinine 2.3) with his creatinine returning to $1.1 \mathrm{mg} / \mathrm{dl}$ on day 18 .

A second episode of AKI followed surgical debridement on day 24 , associated with hemodynamic instability. Nephrology was consulted. Urinalysis revealed dense muddy brown casts consistent with acute tubular necrosis. Fractional excretion of sodium was 3.1\%. Renal ultrasound revealed no hydronephrosis with 15$\mathrm{cm}$ kidneys bilaterally. Bladder pressures were measured daily and remained normal (10-15 mm Hg). By day 40, he developed complete anuria ( $<100 \mathrm{ml}$ urine $/ 24 \mathrm{~h}$ ), which persisted for 31 days. His peak creatinine was $3.7 \mathrm{mg} / \mathrm{dl}$ on day 43 .

Surprisingly, his serum creatinine improved despite anuria, typically ranging from 1.2 to $1.9 \mathrm{mg} / \mathrm{dl}$. As volume loss from his wound discharge was thought to contribute to creatinine clearance, wound electrolytes concentrations were obtained and found similar to serum (table 1). A day 60 serum cystatin C was $1.90 \mathrm{mg} / \mathrm{l}$ (normal range $0.5-1.0 \mathrm{mg} / \mathrm{l}$ ) with same-day creatinine of $1.6 \mathrm{mg}$ / dl.

Despite anuria and AKI, the patient was consistently hypokalemic and hypophosphatemic, often requiring intravenous replacement of both. He received high-protein, high-calorie tube feeds; however, his serum albumin declined from $2.9 \mathrm{~g} / \mathrm{dl}$ to a nadir of $1.9 \mathrm{~g} / \mathrm{dl}$. The hospital course was complicated by bacteremia, 
Table 1. Total input, output, serum electrolytes and electrolytes from wound discharge are provided (serum and wound values approximated each other)

\begin{tabular}{|c|c|c|c|c|}
\hline & \multicolumn{2}{|l|}{ Day 60} & \multicolumn{2}{|l|}{ Day 85} \\
\hline & $\begin{array}{l}\text { serum } \\
\text { values }\end{array}$ & $\begin{array}{l}\text { wound } \\
\text { values }\end{array}$ & $\begin{array}{l}\text { serum } \\
\text { values }\end{array}$ & $\begin{array}{l}\text { wound } \\
\text { values }\end{array}$ \\
\hline Sodium, mEq/l & 140 & 143 & 133 & 134 \\
\hline Potassium, mEq/l & 3.3 & & 3.1 & \\
\hline Chloride, mEq/l & 100 & & 100 & \\
\hline Bicarbonate, mEq/l & 24 & & 21 & \\
\hline Urea nitrogen, mg/dl & 28 & 28 & 100 & 104 \\
\hline Creatinine, $\mathrm{mg} / \mathrm{dl}$ & 1.6 & 1.6 & 1.6 & 1.6 \\
\hline \multicolumn{5}{|l|}{ Input and output } \\
\hline Total input, liters & 42.6 & & 18.4 & \\
\hline Wound drainage, liters & 19.7 & & 8.6 & \\
\hline Urine output, $\mathrm{ml}$ & 0 & & 79 & \\
\hline
\end{tabular}

fungemia, ventilator-associated pneumonia, persistent respiratory failure, atrial fibrillation with rapid ventricular response, and two episodes of cardiac arrest with successful resuscitation. After 45 days of oligoanuria, hemodialysis was initiated on day 85 for volume removal as the patient had increasing oxygen requirements due to concomitant pulmonary edema and Pseudomonas/ Klebsiella pneumonia. On day 91, the patient died of cardiac arrest after a change in his code status to 'do not resuscitate'.

\section{Discussion}

NSTIs frequently present with concomitant AKI. Creatinine on presentation is $52.4 \%$ higher in patients with NSTI as compared to matched controls with other soft tissue infections [1]. Mortality with NSTI is variable (6$76 \%)[2,3]$ with a recent large case series of 89 patients demonstrating a rate of $21.3 \%[2,3]$.

The etiology of AKI is often multifactorial in NSTIs with potential sources including hypoperfusion, abdominal compartment syndrome, rhabdomyolysis, and acute tubular necrosis related to hemodynamic instability, medications, or inflammatory milieu (sepsis/infection). Inpatient mortality for critically ill patients with AKI is high with estimates of $60.3 \%$ (95\% CI 58.0-62.6) [4]. Regardless of its etiology, AKI is associated with increased mortality in the setting of NSTI. In a retrospective single-center cohort study of 166 patients with NSTI over a 5-year period, NSTI with AKI compared to NSTI without AKI conferred an odds ratio of 3.1 for death in multivariate analysis (95\% CI 1.1-9.4, $\mathrm{p}=0.03$ ) [5].
We present the case of a patient with NSTI whose own convective clearance through a large abdominal and lower body wound maintained a modicum of creatinine clearance during sustained anuria. In this unique circumstance, serum creatinine became a deceptive primary determinant of eGFR. Accurate assessment of kidney injury severity is crucial as it impacts prognosis, need for extracorporeal therapy, and medication dosing. The APACHE II score and other indices used in risk stratification of the critically ill employ changes in creatinine as a determinant [6]. Further, increased serum creatinine has been suggested as diagnostic criteria in differentiating NSTIs from non-invasive soft tissue infections such as cellulitis $[1,7]$. Through the use of modern standardized AKI criteria which rely on both serum creatinine and urine output [Acute Kidney Injury Network (AKIN) and Risk Injury Failure Loss End stage (RIFLE)], our patient's diagnosis was never in question; however, refinement of prognosis may have assisted in earlier code status discussions.

As the patient's serum creatinine improved during complete anuria without extracorporeal hemodialysis or hemofiltration, another mechanism for creatinine clearance must have been present. Loss of muscle mass due to multiple tissue debridements and catabolism during prolonged critical illness inherently decreases serum creatinine. However, we postulate much of the daily creatinine clearance was due to convective clearance in sero-sanguineous discharge across his exposed muscle and fascia. The patient had marked volume losses and daily replacement. The recorded wound volume loss underestimated true volume loss secondary to significant evaporative losses and inconsistencies in recording practices. After initial resuscitation, the fluid replacement goal was to keep input and output (including unmeasured losses) approximately even. His inputs are likely a better measure of true volume loss than the recorded volume loss. On average, replacement input was 21.8 liters daily after onset of anuria. Body weight remained similar from onset of anuria until dialysis initiation, decreasing from 207 to $205 \mathrm{~kg}$ over 45 days.

Creatinine clearance is calculated using the formula:

Creatinine clearance $(\mathrm{ml} / \mathrm{min})=$ [urine creatinine/

serum creatinine $\times$ [volume $(\mathrm{ml}) /$ time $(\mathrm{min})]$

In an analogous exercise, the same was done for our patient's creatinine clearance due to wound discharge. As shown in table 1, spot fluid and serum creatinine levels were $1.6 \mathrm{mg} / \mathrm{dl}$. The patient's serum creatinine had only mild day-to-day variance late in his hospital course and spot fluid creatinine was obtained during this period; 
thus, it is reasonable to extrapolate his spot clearance to a 24-hour value. Assuming a 21.8-liter volume loss in $24 \mathrm{~h}$ (his average replacement need), he would clear 349 $\mathrm{mg}$ of creatinine in $24 \mathrm{~h}$. Creatinine clearance would be $15 \mathrm{ml} / \mathrm{min}$. For his age, ethnicity, and creatinine of 1.6 $\mathrm{mg} / \mathrm{dl}$, the MDRD eGFR is $55 \mathrm{ml} / \mathrm{min}$. While the MDRD estimate should be applied with caution during AKI, there is a clear discrepancy between the observed serum creatinine of $1.6 \mathrm{mg} / \mathrm{dl}$ and the calculated creatinine clearance of $15 \mathrm{ml} / \mathrm{min}$. As above, the patient's loss of muscle mass may account for some of this discrepancy. Further, although the patient's weight was stable, it should have decreased with muscle loss. Thus, a dilutional component exists as well [8].

Wound urea clearance is evaluated in a similar way to creatinine clearance. Serum and wound urea values approximated each other (table 1), again suggesting clearance through wound drainage. However, the patient's serum urea gradually increased to over $100 \mathrm{mg} / \mathrm{dl}$. From day 60 to 85, there was an average increase in serum urea of $3 \mathrm{mg} / \mathrm{dl} / \mathrm{day}$. Given the patient's weight of $207 \mathrm{~kg}$, his total body water was approximately 100 liters; thus, his daily increase in total body urea was approximately $3 \mathrm{~g}$. Assuming constant wound urea concentrations over a day, urea clearance ranged between 6 and $23 \mathrm{~g}$ daily, with an average of $14.4 \mathrm{~g} /$ day. The expected daily input of urea would be the clearance ( $14.4 \mathrm{~g}$ ) added to the daily change in total body urea $(3 \mathrm{~g})$ or about $17.4 \mathrm{~g}$. This value is similar to his delivered nutrition therapy (at least $100 \mathrm{~g}$ protein or $16 \mathrm{~g}$ nitrogen daily). Discrepancies lie in the patient's negative nitrogen balance due to catabolic state, daily variation in liters of wound drainage, and daily variation in delivered nutrition.

The application of evidence from burn literature to NSTIs appears relevant as similarities in treatment and complications exist. However, unlike our case, many studies assessing kidney function during recovery from severe burns predominantly note polyuric kidney injury [9-12]. In these polyuric patients, it is not uncommon to see creatinine clearances above $120 \mathrm{ml} / \mathrm{min}[10,13]$. Calculations of creatinine clearance based on serum creatinine failed to accurately estimate 24 -hour urine creatinine clearances in the setting of burns $[13,14]$. The contribution of wound fluid creatinine clearance is infrequently discussed; however, Sosa et al. [15] suggest the burn wound acts as an extrarenal site for creatinine loss. Although lacking anuria, their case holds parallels to our own including correlation of serum and fluid electrolytes and an increase in estimated creatinine clearance with significant wound losses.
An evaluation of AKI in the setting of NSTI or burn should exclude the presence of rhabdomyolysis. The incidence of all-cause AKI associated with critical burns is high at $39.1 \%$ [16]. However, a 10 -year retrospective review of 714 severely burned patients revealed a $1 \%$ incidence of rhabdomyolysis [17]. A smaller retrospective study found the incidence of late-onset rhabdomyolysis to be as high as $9 \%$ in severely burned patients [18]. Rhabdomyolysis has been described in the setting of skin necrosis associated with injection drug use [19]; however, larger trials and case series are lacking. Assessment of renal function in the setting of rhabdomyolysis may be aided by the determination of cystatin C. Large variations in eGFR calculations between cystatin $\mathrm{C}$ and creatinine have been noted during recovery from rhabdomyolysis related AKI [20]. Our patient had an elevated creatinine kinase at the time of admission (664 U/l) which gradually improved over 3 weeks and thus was inconsistent with rhabdomyolysis-associated AKI. Of interest, on hospital day 60 , our patient's cystatin $C$ level was higher than his creatinine $(1.9 \mathrm{mg} / \mathrm{l} \mathrm{vs} .1 .6 \mathrm{mg} / \mathrm{dl}$, respectively). While neither his cystatin $\mathrm{C}$ nor creatinine level are consistent with AKI requiring dialysis, the eGFR estimates based on each are different. The patient's creatinine-based eGFR (MDRD) is $55 \mathrm{ml} / \mathrm{min}$ and his cystatin C-based (Dade Behring) estimate is $34 \mathrm{ml} / \mathrm{min}$ [21]. A potential explanation may be his history of diabetes, which has been shown to be associated with higher levels of cystatin $C$ compared to serum creatinine [22]. Additionally, the eGFR based on cystatin $\mathrm{C}$ is less impacted by the patient's decrease in muscle mass and correlates better with our calculated wound clearance above.

Medication dosing errors are common in the setting of critical illness [23, 24]. In our hospital, eGFR based on the MDRD equation is reported with any serum creatinine level. Despite the safeguards of computerized physician order entry, the patient's renal function was repeatedly overestimated, leading to the overdosing of several medications. A further caveat lies in whether to assess the patient's effective clearance as $0 \mathrm{ml} / \mathrm{min}$ for anuria or include the patient's limited creatinine clearance from his wound in dosing. Again drawing from burn literature, several studies suggest increased antibiotic clearance in the setting of massive burns [25-28]. Data suggests antibiotic clearance is correlated with increased creatinine clearance seen in burns; however, the possibility remains that some of the antibiotic is cleared through sero-sanguineous drainage.

In summary, we present the case of a patient with NSTI who endured 31 consecutive days of complete an- 
uria. His creatinine decreased over this interval without the use of extracorporeal therapy. Instead, his abdominal and lower extremity wound acted as a non-specific filter and the patient's volume loss and replacement were analogous to continuous hemofiltration. During sustained anuria, he maintained a small measure of creatinine clearance through his massive wound output.

\section{Acknowledgement}

This work was supported by National Institute of Health grants T32DK007510, T32GM007019, and K23 DK081616.

\section{References}

-1 Wong CH, Khin LW, Heng KS, Tan KC, Low CO: The LRINEC (Laboratory Risk Indicator for Necrotizing Fasciitis) score: a tool for distinguishing necrotizing fasciitis from other soft tissue infections. Crit Care Med 2004;32:1535-1541.

-2 McHenry CR, Piotrowski JJ, Petrinic D, Malangoni MA: Determinants of mortality for necrotizing soft-tissue infections. Ann Surg 1995;221:558-565.

$>3$ Wong $\mathrm{CH}$, Chang $\mathrm{HC}$, Pasupathy S, Khin LW, Tan JL, Low CO: Necrotizing fasciitis: clinical presentation, microbiology, and determinants of mortality. J Bone Joint Surg Am 2003;85-A:1454-1460.

4 Uchino S, Kellum JA, Bellomo R, Doig GS, Morimatsu H, Morgera S, Schetz M, Tan I, Bouman C, Macedo E, Gibney N, Tolwani A, Ronco C: Acute renal failure in critically ill patients: a multinational, multicenter study. JAMA 2005;294:813-818.

5 Anaya DA, McMahon K, Nathens AB, Sullivan SR, Foy H, Bulger E: Predictors of mortality and limb loss in necrotizing soft tissue infections. Arch Surg 2005;140:151-158.

6 Knaus WA, Draper EA, Wagner DP, Zimmerman JE: Apache II: a severity of disease classification system. Crit Care Med 1985;13: 818-829.

7 Sarani B, Strong M, Pascual J, Schwab CW: Necrotizing fasciitis: current concepts and review of the literature. J Am Coll Surg 2009; 208:279-288.

$\checkmark 8$ Macedo E, Bouchard J, Soroko SH, Chertow GM, Himmelfarb J, Ikizler TA, Paganini EP, Mehta RL: Fluid accumulation, recognition and staging of acute kidney injury in critically ill patients. Crit Care 2010;14:R82.

9 Schiavon M, Di Landro D, Baldo M, De Silvestro G, Chiarelli A: A study of renal damage in seriously burned patients. Burns Incl Therm Inj 1988;14:107-112.
10 Haynes BW Jr, DeBakey ME, Denman FR: Renal function studies of severely burned patients; a preliminary report. Ann Surg 1951; 134:617-625.

11 Cameron JS: Disturbances of renal function in burnt patients. Proc R Soc Med 1969;62: 49-50.

12 Planas M, Wachtel T, Frank H, Henderson LW: Characterization of acute renal failure in the burned patient. Arch Intern Med 1982; 142:2087-2091.

13 Conil JM, Georges B, Fourcade O, Seguin T, Lavit M, Samii K, Houin G, Tack I, Saivin S: Assessment of renal function in clinical practice at the bedside of burn patients. $\mathrm{Br} \mathrm{J}$ Clin Pharmacol 2007;63:583-594.

$>14$ Lott RS, Uden DL, Wargin WA, Strate RG, Zaske DE: Correlation of predicted versus measured creatinine clearance values in burn patients. Am J Hosp Pharm 1978;35: 717-720.

15 Sosa JL, Ward CG, Hammond JS: The relationship of burn wound fluid to serum creatinine and creatinine clearance. J Burn Care Rehabil 1992;13:437-442.

16 Mustonen KM, Vuola J: Acute renal failure in intensive care burn patients (ARF in burn patients). J Burn Care Res 2008;29:227-237.

17 Stollwerck PL, Namdar T, Stang FH, Lange T, Mailander P, Siemers F: Rhabdomyolysis and acute renal failure in severely burned patients. Burns 2011;37:240-248.

18 Bache SE, Taggart I, Gilhooly C: Late-onset rhabdomyolysis in burn patients in the intensive care unit. Burns 2011;37:1241-1247.

19 Hengge UR, Beiderlinden M, Otterbach F, Groeben H, Nast-Kolb D, Mehnert WH, Peters J, Schmid KW: 31-year-old injection drug user with massive skin necrosis and shock. Dermatology 2003;206:169-171.

20 Yap M, Lamarche J, Peguero A, Courville C: Serum cystatin $C$ versus serum creatinine in the estimation of glomerular filtration rate in rhabdomyolysis. J Ren Care 2011;37:155157.
21 Larsson A, Malm J, Grubb A, Hansson LO: Calculation of glomerular filtration rate expressed in $\mathrm{ml} / \mathrm{min}$ from plasma cystatin C values in $\mathrm{mg} / \mathrm{l}$. Scand J Clin Lab Invest 2004; 64:25-30.

22 Stevens LA, Schmid CH, Greene T, Li L, Beck GJ, Joffe MM, Froissart M, Kusek JW, Zhang YL, Coresh J, Levey AS: Factors other than glomerular filtration rate affect serum cystatin C levels. Kidney Int 2009;75:652-660.

23 Colpaert K, Claus B, Somers A, Vandewoude $\mathrm{K}$, Robays H, Decruyenaere J: Impact of computerized physician order entry on medication prescription errors in the intensive care unit: a controlled cross-sectional trial. Crit Care 2006;10:R21.

24 McCoy AB, Peterson JF, Gadd CS, Danciu I, Waitman LR: A system to improve medication safety in the setting of acute kidney injury: Initial provider response. AMIA Annu Symp Proc 2008:1051.

25 Loirat P, Rohan J, Baillet A, Beaufils F, David $\mathrm{R}$, Chapman A: Increased glomerular filtration rate in patients with major burns and its effect on the pharmacokinetics of tobramycin. N Engl J Med 1978;299:915-919.

26 Conil JM, Georges B, Lavit M, Seguin T, Tack I, Samii K, Chabanon G, Houin G, Saivin S: Pharmacokinetics of ceftazidime and cefepime in burn patients: the importance of age and creatinine clearance. Int J Clin Pharmacol Ther 2007;45:529-538.

27 Weinbren MJ: Pharmacokinetics of antibiotics in burn patients. J Antimicrob Chemother 1999;44:319-327.

28 Dolton $\mathrm{M}, \mathrm{Xu} \mathrm{H}$, Cheong E, Maitz P, Kennedy P, Gottlieb T, Buono E, McLachlan AJ: Vancomycin pharmacokinetics in patients with severe burn injuries. Burns 2010;36: 469-476. 